kard. Stanisław Dziwisz

\title{
PERSONALISTYCZNY CHARAKTER PRAW CZLOWIEKA I KOMUNIJNA WIZJA PRAW NARODÓW W NAUCZANIU ŚW. JANA PAWŁA II
}

Zaznaczmy na samym wstępie, że Kościół od początku swego istnienia wnosi twórczy wkład w formułowanie praw człowieka i praw narodów, a także w ich poprawną interpretację i praktyczną realizację. Wkład Jana Pawła II w tej dziedzinie jest niepodważalny. Nie bez powodu nazywany jest on papieżem praw człowieka. Ojciec święty bronił niestrudzenie godności ludzkiej, stając na straży życia od jego początku aż do naturalnej śmierci. Na forach międzynarodowych upominał się o los prześladowanych i dyskryminowanych przez różnorakie reżimy państwowe i ideologiczne. Troska o człowieka była głęboko zapisana w jego sercu. Świadczą o tym niezliczone dokumenty, przemówienia i spotkania. Los człowieka, jego prawo do życia, do wolności, do respektowania naturalnej i nadprzyrodzonej godności, były dla Jana Pawła II ważnym punktem odniesienia w nauczaniu i pełnionej misji głowy Kościoła. Wiele postulatów ojca świętego w dziedzinie obrony i poszanowania praw człowieka wybrzmiewa dziś z nową siłą, a jego pojmowanie norm regulujących zasady życia społecznego może rzucić nowe światło na rzeczywistość, w jakiej obecnie żyjemy.

\section{Prawa Boga}

Jean-Paul Sartre przypisał Dostojewskiemu słowa: „Gdyby Bóg nie istniał, wszystko byłoby dozwolone"1.

${ }^{1}$ Jeśli Boga nie ma. Žižek, Sartre, Dostojewski wraz z dodaniem pouczających wypisów z, „Braci Karamazow", http://kompromitacje.blogspot.com/2014/01/jesli-boga-nie-ma.html (27.10.2017). (Sartre cytował Dostojewskiego w swoim wystąpieniu wygłoszonym na konferencji klubu 
Jeśli wszystko wolno, to nie ma praw człowieka, gdyż znajdują się one wówczas w swoistej próżni. Zanim więc zaczniemy analizować prawa człowieka, należy odpowiedzieć na proste, niemniej zasadnicze pytanie: a co z prawami Boga? Chodzi zarówno o respektowanie właściwego miejsca Boga w życiu ludzkim, jak i o pełnienie woli Bożej w naszej codzienności. Od czasu wybuchu rewolucji francuskiej w 1789 roku zainteresowanie prawami człowieka i upowszechnianie haseł: wolności, równości, postępu, demokracji oraz niezależności nauki, wypierało powoli z ludzkiej świadomości zagadnienie praw Boga. Tymczasem Bóg ma prawo do obecności w świecie. Jest przecież jego Stwórcą, jest również Zbawicielem świata i to od Boga ostatecznie zależą losy świata i człowieka.

Jedynie Bóg jest dawcą życia i to On decyduje o tym, kiedy to życie dobiega kresu. Bóg ma prawo ustalania dla ludzi reguł postępowania i skorzystał z tego prawa, zostawiając nam między innymi Dekalog. Bóg ma prawo do interwencji w naszym życiu. Ma prawo do roztaczania opieki nad nami, co nazywamy działaniem Bożej Opatrzności, a więc ma prawo do ukierunkowania naszego życia, do pomagania nam, do wspierania swoją łaską. Bóg ma również prawo osądzania naszych zachowań i czynów, jak i wymierzania nagrody lub kary. To wszystko nie przeczy temu, że Bóg szanuje wolność człowieka. Stworzył go przecież na swój obraz i podobieństwo. Stworzył go rozumnym i zdolnym do podejmowania wolnych decyzji, choć - dodajmy - z wolnością łączy się także odpowiedzialność.

\section{Wartość prawa naturalnego}

Ważnym punktem wyjścia do naszych rozważań jest przekonanie Jana Pawła II, ukształtowane na bazie Objawienia, że źródłem wszelkiego prawa jest prawo naturalne. Istnienie prawa naturalnego jest kwestionowane przez pozytywistów prawnych, którzy mówią wyłącznie o źródłach stanowienia prawa, takich jak parlamenty państwowe czy instytucje międzynarodowe. Trzeba jednak powiedzieć, że wartość prawa naturalnego bywa rozmywana także przez jego zwolenników. Twierdzi się mianowicie często, że prawo naturalne jest niezmienne w swojej istocie, ale zmienne w swoim istnieniu, bo uzależnione od kontekstów cywilizacyjnych, kulturowych i uwarunkowań historycznych. Podważa to rolę prawa naturalnego jako trwałego i niezmiennego właśnie punktu odniesienia.

Maintenant w roku 1945 roku, a wydanym w roku następnym pod tytułem Egzystencjalizm jest humanizmem: „Dostojewski napisał: «Gdyby Bóg nie istniał, wszystko byłoby dozwolone»” [w oryginale: «Si Dieu n’existait pas, tout serait permis»]. To właśnie jest punktem wyjścia dla egzystencjalistów. W rzeczy samej, wszystko jest dozwolone, jeżeli Bóg nie istnieje, i w konsekwencji człowiek jest osamotniony, gdyż nie znajduje ani w sobie, ani poza sobą punktu oparcia”). 
Jan Paweł II, jeszcze jako młody kapłan, podjął refleksję etyczną nad prawem naturalnym i w bardzo klarowny sposób tłumaczył, czym ono jest. „W prawie natury - pisał - tak jak w każdym prawie, musi być jakoś obecny Prawodawca. Rzecz jasna, że natura sama prawodawcą owym nie jest, ona tylko pozwala istocie rozumnej odczytywać myśli i wolę Prawodawcy. Człowiek, zarówno jednostka, jak i społeczeństwo, zastaje tę myśl i wolę wyrażoną w naturze, w jej zdrowych skłonnościach, w tym porządku, do jakiego te zdrowe skłonności różnych natur są skierowane"2.

Jan Paweł II prawa człowieka i prawa narodów ujmuje zawsze w aspekcie wspólnotowym, czyli - możemy powiedzieć - w aspekcie personalizmu komunijnego. Warto nadmienić, że u podstaw uchwalonych dotychczas praw człowieka, zwłaszcza uchwalonej przez Zgromadzenie Ogólne ONZ Powszechnej Deklaracji Praw Człowieka, leżało prawo naturalne. Jeśli więc to prawo się zakwestionuje, stracą rację bytu prawa człowieka.

\section{Personalistyczny charakter praw człowieka według Jana Pawła II}

W personalizmie Jana Pawła II istotne są trzy sprawy: tajemnica ludzkiego istnienia, podmiotowość i przedmiotowość osobowa oraz relacyjność człowieka. W kontekście naszych rozważań o prawach człowieka szczególne znaczenie mają dwie ostatnie kwestie. Człowiek bowiem jest podmiotem praw, gdyż je stanowi, ale zarazem jest przedmiotem troski prawa. Przykładem podmiotowości człowieka jest postulowana przez Jana Pawła II opcja na rzecz ubogich. W 1989 roku w Lourdes odbyło się sympozjum, podczas którego zwracano uwagę na konieczność przewartościowania - w duchu encykliki Dives in misericordia - relacji między człowiekiem, który daje, a tym, który otrzymuje. Postulowano konieczność uczestnictwa ubogich w formułowaniu praw, które ich dotyczą, bo do tej pory prawa odnoszące się do ubogich były jedynie wynikiem kompromisu między możnymi tego świata. Pewne jest, że każdy człowiek, otrzymując, równocześnie daje. Przysługujące każdemu z nas uprawnienia powinny nas angażować, uaktywniać i mobilizować do działania. Dotykamy tutaj zasady uczestnictwa, o której Karol Wojtyła pisze w książce Osoba i czyn. Człowiek jest relacyjny, bo w jego naturę wpisane jest tworzenie wspólnoty. Temu zaś służy dialog, podejmowany również w dziedzinie stanowienia praw. Czytamy u kardynała Wojtyły: „Zasada dialogu dlatego jest tak trafna, że nie uchyla się od napięć, konfliktów i walk [...], a równocześnie podejmuje właśnie to, co w nich jest prawdziwe i słuszne, co może być

2 K. Wojtyła, Elementarz etyczny, Wrocław 1982, s. 56. 
źródłem dobra dla ludzi”3. Personalizm Jana Pawła II, właśnie przez to, że jest personalizmem dialogicznym, stał się personalizmem komunijnym ${ }^{4}$.

Personalistyczny wymiar praw człowieka rodzi się na gruncie naturalnej i nadprzyrodzonej godności osoby ludzkiej. Naturalna godność ludzi wynika z ich rozumności i wolności. Godność nadprzyrodzona natomiast nadawana jest wraz z powołaniem do zbawienia. W takiej koncepcji praw człowieka uprawnienia i powinności wiążą się przede wszystkim z ochroną ludzkiego życia, od poczęcia aż do naturalnej śmierci. W personalistycznym ujęciu praw człowieka istnieje równowaga między uprawnieniami a powinnościami. Dochodzenie własnych uprawnień kończy się tam, gdzie zaczynają się obowiązki wobec innych osób czy wspólnot.

Prawa ludzkie są też zhierarchizowane. Najważniejsze są prawa fundamentalne, a więc prawo do życia, prawo do życia godnego, prawo do osobowego rozwoju, tak indywidualnego, jak i społecznego. Po nich następują prawa kardynalne: prawo do prawdy, do wolności, do sprawiedliwości, do miłości. Dopiero w trzeciej kolejności mówimy o prawach pochodnych. Należą do nich m.in. prawa kobiet, prawa dzieci, prawo do informacji czy prawo do migracji. W takiej sytuacji prawa kobiet ustępują przed ważniejszym prawem, jakim niezaprzeczalnie jest prawo do życia. W rzeczywistości, która nas otacza, dochodzi do tworzenia praw fałszywych, które manipulują ludzką świadomością i uzurpują sobie najważniejsze miejsce w hierarchii praw.

\section{Komunijne ujęcie praw narodów przez Jana Pawła II}

Komunijny charakter praw człowieka wynika ze społecznego aspektu natury ludzkiej, która kształtuje więzi międzyludzkie. Komunia, zdaniem Jana Pawła II, zaczyna się wtedy, kiedy ludzie „wiedzą, że mają żyć dla drugich i z drugimi, wiedzą, że ich życie ma sens, o ile stają się darem bezinteresownym dla drugich" Według Wojtyły osoba jako taka ma wymiar komunijny w narodzie i w Kościele. Communio polega na oddaniu siebie innym w miłości. Tłumaczy on, że komunia opiera się na uczestnictwie osób w dobru wspólnym i zdolności do współdziałania $\mathrm{z}$ innymi ${ }^{6}$.

Gdy chodzi o naród, communio obejmuje zarówno relacje interpersonalne, jak i szeroko rozumiane stosunki społeczne. Naród, jako wspólnota naturalna, trwała i autonomiczna, powstaje na gruncie ojczyzny pochodzenia, łączy ludzi w żywy

3 K. Wojtyła, Osoba i czyn, Kraków 1985, s. 354.

4 Por. Jan Paweł II, Przekroczyć próg nadziei, Lublin 1996, s. 102n. (komunia opiera się na przykazaniu miłości i oznacza życie z drugimi i dla drugich).

5 Jan Paweł II, Przekroczyć próg nadziei, dz. cyt., s. 102.

${ }_{6}$ Por. K. Wojtyła, Osoba i czyn, dz. cyt., s. 348n. 
organizm, który spajają: wspólna przestrzeń egzystencji, dzieje, tradycja, język, religia i kultura. Ten organizm ma charakter materialny, psychiczny i społeczny, jest żywą wspólnotą zarówno fizyczną, jak i duchową. Elementami tej pierwszej są na przykład: ziemia, przyroda, gospodarka, dziedzictwo, tradycja, pamięć zbiorowa. Do warstwy duchowej należą: język, doświadczenie, sztuka, zmysł etyczny, kultura ducha i religia, także Kościół, i poczucie narodowej misji.

Narody nie tylko żyją na ziemi obok siebie, ale powinny ze sobą współdziałać, a ich wzajemne relacje regulowane są przez prawa narodów. To koncepcja, która zrodziła się już w starożytności, w czasach nowożytnych była stosowana na określenie dzisiejszego prawa międzynarodowego. Poważny wkład w rozwój praw narodów wniósł Kościół, a w czasach najnowszych - Jan Paweł II. Warto przywołać jego dwa wystąpienia na forum Zgromadzenia Ogólnego ONZ: z 2 października 1979 roku oraz 5 października 1995 roku. W pierwszym przemówieniu papież mówił, że wszelka działalność polityczna, zarówno krajowa, jak i międzynarodowa, winna respektować prawa człowieka i służyć jego dobru. Wyraźnie podkreślał, że istnieją systemy polityczne, które respektowanie praw człowieka jedynie deklarują, a nawet dekretują, ale w praktyce ich nie przestrzegają i dyskryminują ludzi. Dziś rozumiemy, jakie wrażenie musiały wówczas wywrzeć słowa ojca świętego zwłaszcza na przedstawicielach krajów reżimu komunistycznego w Europie Wschodniej i Związku Sowieckiego ${ }^{7}$.

W drugim przemówieniu, wygłoszonym już w zupełnie innym kontekście geopolitycznym (5 października 1995 roku), Jan Paweł II mówił, że postmodernizm i wielokulturowość często negują uniwersalizm praw człowieka, zapominając o tym, że prawo naturalne zapisane jest w ludzkich sercach i stanowi „specjalną gramatykę”, której potrzebuje współczesny świat. „Z tego też płyną prawa narodów, które nie są niczym innym, jak prawami człowieka, ujętymi na tej szczególnej płaszczyźnie życia wspólnotowego" - podkreślał papież.

Jan Paweł II zaznaczał ponadto, że nie da się zbudować prawdziwej komunii w narodzie i komunii narodów, jeśli z ich życia zostaną wyrugowane relacje z Bogiem. Bez relacji z Bogiem, a więc bez wertykalnego wymiaru wspólnoty, wypaczeniu ulegają relacje międzyludzkie, czyli wymiar horyzontalny. Przemawiając w 1991 roku w Lubaczowie, papież mówił o państwie, które jest organizacją i reprezentacją narodu. „Postulat neutralności światopoglądowej jest słuszny głównie w tym zakresie, że państwo powinno chronić wolność sumienia i wyznania wszystkich swoich obywateli, niezależnie od tego, jaką religię lub światopogląd oni wyznają. Ale postulat, ażeby do życia społecznego i państwowego w żaden

7 Por. Jan Paweł II, Homilie i przemówienia z pielgrzymek. Ameryka Pótnocna i Południowa. Dzieła zebrane, t. 12, Kraków 2009, s. 24-35.

${ }^{8}$ Jan Paweł II, Homilie i przemówienia..., dz. cyt., s. 127-135. 
sposób nie dopuszczać wymiaru świętości, jest postulatem ateizowania państwa i życia społecznego, i niewiele ma wspólnego ze światopoglądową neutralnością" Tak mówił Jan Paweł II.

Dziś, w kontekście przemian kulturowych i cywilizacyjnych w naszej Ojczyźnie i w Europie, te słowa nabierają szczególnej aktualności.

\section{Abstract \\ Personalistic character of human rights and the conception of the rights of nations viewed as a community in the teaching of John Paul II}

The numerous principles of Pope John Paul II concerning the defense of and respect for human rights are relevant today. He teaches that human and national rights are always encompassed in the public consciousness. He emphasizes that it is impossible to build a community in the nation and, in turn, a community of nations, without the vertical dimension of God. The horizontal dimension of the community, in other words, interpersonal relationships, risk being distorted.

9 Jan Paweł II, Homilia w czasie Mszy św. - Lubaczów, 3 czerwca 1991, [w:] Jan Paweł II, Pielgrzymki do Ojczyzny: 1979, 1983, 1987, 1991, 1995, 1997, 1999. Przemówienia, homilie, Kraków 1999, s. 598. 